Volume 3 (September, 2015)

\title{
Pengaruh Kualitas Produk Dan Kualitas Pelayanan Terhadap Kepuasan Konsumen Dan Minat Beli Ulang
}

\author{
Arfiani Bahar ${ }^{1)}$ \& Herman Sjaharuddin ${ }^{2)}$ \\ viviot.vhie@yahoo.com
}

\begin{abstract}
1) Mahasiswa Program Studi Manajemen pada Sekolah Tinggi Ilmu Ekonomi Bongaya Makassar

2) Dosen Program Studi Manajemen pada Sekolah Tinggi Ilmu Ekonomi Bongaya Makassar
\end{abstract}

\begin{abstract}
ABSTRAK
Penelitian ini bertujuan untuk menguji dan menganalisis kualitas produk, kualitas pelayanan, kepuasan konsumen dan minat beli ulang pada konsumen di McDonald's Alauddin Makassar. Populasi dalam penelitian ini adalah konsumen McDonald's Alauddin Makassar. Sampel berjumlah 80 responden. Hasil pengujian hipotesis juga menggunakan analisis jalur melalui SPSS Versi 21.0 membuktikan bahwa kualitas produk dan kualitas pelayanan mempengaruhi kepuasan konsumen, kualitas pelayanan dan kepuasan konsumen mempengaruhi minat beli ulang, kualitas produk tidak mempengaruhi minat beli ulang.
\end{abstract}

Kata kunci : Kualitas Produk, Kualitas Pelayanan, Kepuasan Konsumen, Minat Beli Ulang

\section{ABSTRACT}

This study aims to examine and analyze the quality of products, service quality, customer satisfaction and intention to buying on at McDonald's Alauddin Makassar. The population in this study are consumers of McDonald's Alauddin Makassar city. Samples numbered 80 respondents. Results of hypothesis testing are also using path analysis through SPSS version 21.0 prove that the quality of product and service quality affects on customer satisfaction, quality of service and customer satisfaction affect on intention to buying, the quality of the product does not affect on intention to buying.

Keywords: $\quad$ Product, service quality, customer satisfaction, intention to buying

\section{Latar Belakang}

Pertumbuhan ekonomi dunia yang dinamis dan kompleks memberikan dampak terhadap pertumbuhan ekonomi di Indonesia. Hal tersebut dapat dilihat, salah satunya melalui menjamurnya usaha franchise yang menyediakan aneka ragam fast food (makanan cepat saji), seperti KFC, McDonald's, Pizza Hut, Wendy's burger serta bentuk usaha franchise lainnya yang ada di Indonesia. Franchise merupakan salah satu usaha yang mengalami peningkatan yang sangat pesat.

Author : Arfiani Bahar \& Herman Sjaharuddin (14-34)

Halaman 14

Volume 3 (September, 2015) https://dx.doi.org/10.17605/OSF.IO/TC2FE 


\section{JURNAL ORGANISASI DAN MANAJEMEN}

Volume 3 (September, 2015)

Kondisi tersebut diakibatkan karena banyaknya pebisnis (wirausahawan) mengambil peluang dengan mendirikan usaha franchise / restoran cepat saji (Sundalangi dkk., 2014).

Pertumbuhan industri franchise / restoran cepat saji di Indonesia menunjukkan perkembangan yang relatif pesat, berdasarkan survey yang dilakukan Roy Morgan pada tahun (Single Source, 2009) terhadap lebih dari 25 ribu responden berusia 14 tahun ke atas menunjukkan selama kuartal I/2009 sebanyak $54 \%$ responden pernah mengkonsumsi lebih dari sekali makanan pada restoran franchise / cepat saji, angka ini melonjak dibandingkan dua tahun lalu yakni hanya sebesar $48 \%$ penduduk Indonesia yang pernah mengkonsumsi makanan pada restoran franchise / cepat saji (Aryani dan Rosinta, 2010).

Berdasarkan temuan tersebut, dapat dijelaskan bahwa selera masyarakat untuk mengkonsumsi makanan pada restoran franchise / siap saji tergolong pada kategori yang cukup tinggi. Melihat indikasi ini, menunjukkan adanya peluang besar bagi pertumbuhan bisnis restoran cepat saji. Iklim kompetisi dalam industri restoran cepat saji pun semakin terasa dengan bermunculannya berbagai restoran cepat saji. Pangsa pasar restoran franchise / siap saji berdasarkan tiga peringkat teratas ditempati oleh Kentucky Fried Chicken (KFC) pada peringkat pertama dengan nilai pangsa pasar $42 \%$, kemudian peringkat kedua ditempati oleh Restoran Sederhana (Tradisional) dengan nilai pangsa pasar 35\% dan yang terakhir diduduki oleh McDonald's dengan nilai pangsa pasar sebesar 23\%.

Berdasarkan pra penelitian yang dilakukan, ditemukan adanya fakta yang menegaskan bahwa McDonald's belum mampu memimpin pasar disebabkan karena perusahaan belum mampu memahami secara optimal perilaku konsumen dan memperoleh pemahaman yang baik tentang bagaimana konsumen berpikir, kebiasaan konsumen dalam membeli dan faktor yang mempengaruhinya dalam melakukan pembelian ulang sehingga dengan pengetahuan dan pemahaman tersebut perusahaan dapat mengetahui kebutuhan dan harapan dari konsumen. Fakta tersebut memotivasi peneliti untuk melakukan penelitian dengan menganalisis kualitas produk dan kualitas layanan produk McDonald's sebagai pemicu kepuasan konsumen dan minat beli ulang pada McDonald's

Kemampuan usaha franchise untuk berkembang sangat dipengaruhi oleh minat beli konsumen (Sundalangi dkk., 2014), minat beli konsumen dipengaruhi oleh beberapa faktor, yaitu; (1) kualitas produk; (2) kualitas layanan; (3) kepuasan konsumen (Puspitasari, 2006; Rahma, 2007; Saidani dan Arifin, 2012). Teori kontrol pribadi (personal control theory), menjelaskan bahwa kepuasan didasarkan pada pengalaman hidup seseorang atau pekerjaan berhubungan dengan persepsi melalui perbandingan psikologis antara tindakan dan hasil yang diinginkan (Rotter,1966; dalam Peterson et al., 1993). Teori ini menjelaskan bahwa kecenderungan konsumen untuk melakukan pembelian ulang disebabkan karena tingginya kepuasan yang dimiliki oleh konsumen dan tingginya kualitas layanan yang dirasakan serta tingginya kualitas produk yang digunakan oleh konsumen (Puspitasari, 2006; Rahma, 2007; Saidani dan Arifin, 2012).

Minat beli merupakan perilaku konsumen yang menunjukkan sejauh mana komitmennya untuk melakukan pembelian. Kebutuhan dan keinginan konsumen akan barang dan jasa berkembang dari masa ke masa dan mempengaruhi perilaku mereka dalam pembelian produk (Mandasari dan Soesanto, 2011). Minat beli dapat didefinisikan sebagai suatu kemungkinan kegiatan yang dilakukan oleh konsumen 


\section{JURNAL ORGANISASI DAN MANAJEMEN}

Volume 3 (September, 2015)

untuk membeli produk (Doods et al., 1991; dalam Dwityanti, 2008). Pengukuran yang digunakan dalam menjelaskan minat beli konsumen terdiri dari: (1) minat transaksional, (2) minat refrensial, (3) minat preferensial, (4) minat eksploratif (Ferdinand, 2002).

Dalam kondisi persaingan yang ketat, hal utama yang harus diprioritaskan adalah kepuasan pelanggan (customer satisfaction) yang pada akhirnya akan menarik minat pelanggan untuk membeli ulang suatu produk, sehingga perusahaan dapat bertahan, bersaing dan menguasai pangsa pasar. Minat beli ulang suatu produk dipengaruhi langsung oleh kepuasan pelanggan pada merek yang diakumulasikan melalui waktu, jika pelanggan puas terhadap produk atau layanan yang diberikan akan menimbulkan kesetiaan pelanggan sehingga membuat pelanggan melakukan pembelian ulang (repurchase) di masa yang akan datang (Thamrin, 2003).

Kepuasan adalah perasaan senang atau kecewa seseorang yang berasal dari perbandingan antara kesannya terhadap kinerja (hasil) sesuatu produk dengan harapannya (Kotler, 2005). Terdapat tiga dimensi dalam mengukur kepuasan pelanggan secara universal yaitu; (1) atribut produk (attributes related to product); (2) atribut layanan (attributes related to service); (3) atribut pembelian (attributes related to purchase) (Dutka; dalam Cahyono Melinda, 2008:11). Bukti empiris yang menunjukkan adanya hubungan yang positif antara kepuasan konsumen dengan minat beli ulang ditunjukkan dalam penelitian yang dilakukan Diana Puspitasari (2006) bahwa semakin tinggi kepuasaan konsumen maka semakin tinggi minat beli ulang konsumen.

Variable lain yang mempengaruhi minat beli ulang, salah satunya adalah kualitas layanan, kualitas layanan adalah model yang menggambarkan kondisi pelanggan dalam membentuk harapan akan layanan dari pengalaman masa lalu, promosi dari mulut ke mulut, dan iklan dengan membandingkan pelayanan yang mereka harapkan dengan apa yang mereka terima/rasakan (Kotler, 2005:153). Terdapat lima dimensi kualitas pelayanan (servqual), yaitu ; (1) bukti fisik (tangibles), (2) keandalan (realibility), (3) daya tangkap (responsiveness), (4) jaminan (assurance), (5) dukungan (emphaty).(Parasuraman et al., $1990: 21$ ).

Kualitas layanan berdasarkan temuan peneliti sebelumnya memberikan bukti bahwa terdapat pengaruh yang signifikan antara kualitas layanan terhadap kepuasan konsumen (Rizan dan Andika, 2011). Kualitas layanan, selain memberikan pengaruh terhadap kepuasan konsumen, juga memberikan pengaruh terhadap minat beli. Hal ini ditunjukkan penelitian Rahma (2007) bahwa kualitas layanan berpengaruh positif dan signifikan terhadap minat beli konsumen.

Kualitas produk mencerminkan kemampuan produk untuk menjalankan tugasnya yang mencakup daya tahan, kehandalan atau kemajuan, kekuatan, kemudahan dalam pengemasan dan reparasi produk dan ciri-ciri lainnya (Kotler dan Amstrong,1997; dalam Rizan dan Andika, 2011). Produk dipandang penting oleh konsumen dan dijadikan dasar pengambilan keputusan. Dalam penelitian ini akan digunakan tiga indikator yang mencirikan percaya diri yaitu: (1) rasanya yang enak; (2) fitur produk; (3) daya tahan kemasan (Kotler, 2005). Kualitas produk berdasarkan peneliti sebelumnya memberikan bukti bahwa terdapat pengaruh yang tidak signifikan antara kualitas produk terhadap kepuasan konsumen (Rizan dan Andika, 2011). Selain memberikan pengaruh yang tidak signifikan, kualitas produk juga memberikan pengaruh yang positif terhadap kepuasan konsumen dalam 


\section{JURNAL ORGANISASI DAN MANAJEMEN}

Volume 3 (September, 2015)

penelitian yang dilakukan Haryanto (2013). Kualitas produk, selain memberikan pengaruh terhadap kepuasan konsumen, juga memberikan pengaruh terhadap minat beli. Hal ini ditunjukkan penelitian oleh Basrah Saidani dan Samsul Arifin (2012) bahwa Kualitas Produk memiliki pengaruh langsung yang positif terhadap Minat Beli Ulang konsumen.

\section{Tinjauan Pustaka}

\section{Kualitas Produk}

Kualitas produk (product quality) didefinisikan sebagai evaluasi menyeluruh pelanggan atas kebaikan kinerja barang atau jasa (Mowen dan Minor, 2002). Perusahaan harus memiliki kualitas yang baik atau sesuai dengan harga yang ditawarkan ketika menjual produk maupun jasa di dalam menjalankan suatu bisnis. Menurut Kotler dan Amstrong (2001) kualitas adalah karakteristik dari produk dalam kemampuan untuk memenuhi kebutuhan - kebutuhan yang telah ditentukan dan bersifat laten. Sedangkan produk adalah segala sesuatu yang dapat ditawarkan kepasar untuk mendapatkan perhatian, dibeli, digunakan, atau dikonsumsi yang dapat memuaskan keinginan atau kebutuhan.

Menurut Kotler, 1995 (dalam Lembang dan Sugiono, 2010) ada tiga indikator kualitas produk yaitu:

a. Rasanya yang enak

Ini menyangkut penilaian konsumen terhadap cita rasa pada produk yang di tawarkan perusahaan kepada konsumen. Produk-produk yang bermerek terkenal biasanya dipersepsikan lebih berkualitas dan terjamin rasanya dibanding dengan merek-merek yang tidak didengar.

b. Fitur produk

Dimensi fitur merupakan karakteristik atau ciri-ciri tambahan yang melengkapi manfaat dasar suatu produk. Fitur bersifat pilihan atau option bagi konsumen. Kalau manfaat utama sudah standar, fitur sering kali ditambahkan. Idenya, fitur bisa meningkatkan kualitas produk kalau pesaing tidak memiliki.

c. Daya Tahan kemasan

Daya tahan menunjukan usia produk, yaitu jumlah pemakian suatu produk sebelum produk itu digantikan atau rusak. Semakin lama daya tahannya tentu semakin awet, produk yang awet akan dipersepsikan lebih berkualitas dibanding produk yang cepat habis atau cepat diganti.

\section{Kualitas Layanan}

Bouman dan Wiele (1992: 5) bahwa dimensi-dimensi kualitas layanan meliputi layanan pada konsumen, tangibles atau sesuatu yang nampak pada penyedia jasa, serta keyakinan akan jaminan yang diberikan penyedia jasa. Layanan yang dimaksud dalam penelitian ini adalah layanan yang sesuai dengan standar yang telah ditentukan, misalnya proses pengenalan produk secara baik terhadap konsumen.

Menurut Zeithaml et al. (1990:19) Kualitas Layanan adalah ketidaksesuaian antara harapan atau keinginan konsumen dengan persepsi konsumen. Kualitas layanan mempunyai banyak karakteristik yang berbeda sehingga kualitas layanan sulit untuk didefinisikan atau diukur. Karakteristik Kualitas Layanan menurut Zeithaml et al. (1990) terdapat tiga karakteristik kualitas layanan yaitu intangible 


\section{JURNAL ORGANISASI DAN MANAJEMEN}

Volume 3 (September, 2015)

(tidak dapat diraba atau dinyatakan), heterogeneous (beraneka ragam) dan indivisible (tidak dapat dibagi) atau inseparability (tidak dapat dipisahkan).

a) Intangible Kualitas layanan bersifat intangible yaitu tidak dapat diraba karena kualitas layanan adalah hasil bukan suatu produk.

b) Heterogeneous Kualitas layanan bersifat heterogeneous yaitu beraneka ragam karena hasil tergantung dari perbuatan yang dijalankan oleh individual yang terlibat, dari produsen ke konsumen yang mungkin tidak mempunyai ekspektasi yang sama (Zeithaml et al., 1990).

c) Indivisible atau Inseparability Kualitas layanan bersifat indivisible atau inseparability karena proses produksi dan konsumsi terjadi secara serempak. Schneider \& White (2004, p.7) menyatakan bahwa fitur yang terpenting dari inseparability dari layanan adalah perusahaan harus berjuang untuk memastikan bahwa ketika layanan sedang diproduksi produsen harus mengetahui jumlah maksimal dari konsumen yang akan memakai layanan tersebut.

Parasuraman et al (1990:21, dalam Saidani dan Arifin, 2012) menyatakan bahwa terdapat lima dimensi kualitas pelayanan (servqual) , yaitu :

(1) Tangibles, merupakan faktor-faktor yang dapat dilihat, didengar, dan disentuh. Di dalam tangible juga termasuk lingkungan fisik, fasilitas, dan penampilan dari kontak pribadi.

(2) Realibility, merupakan kemampuan untuk menunjukkan bahwa pelayanan yang diberikan dapat dipercaya dan akurat.

(3) Responsive, merupakan kesedian untuk membantu konsumen dan memberikan pelayanan yang cepat.

(4) Assurance, merupakan pengetahuan dan kebaikan karyawan dan kemampuannya untuk memperoleh kepercayaan dan keyakinan.

(5) Empathy adalah kepedulian, perhatian individu yang diberikan perusahaan kepada konsumennya.

\section{Kepuasan Konsumen}

Kotler (2000) menyebutkan kepuasan adalah perasaan senang atau kecewa seseorang yang berasal dari perbandingan antara kesannya terhadap kinerja (hasil) sesuatu produk dengan harapannya. Konsumen yang puas akan membeli "produk" lain yang dijual oleh perusahaan, sekaligus menjadi "pemasar" yang efektif melalui Word of mouth yang bernada positif. Hal ini dapat membantu meningkatkan penjualan dan kredibilitas perusahaan.

Oliver (1993; dalam Cahyono Melinda, 2008) menyatakan bahwa kepuasan merupakan tingkat perasaan seseorang setelah membandingkan kinerja atau hasil yang dirasakannya dengan harapan. Menurut Dutka (dalam Cahyono Melinda, 2008:11) terdapat tiga dimensi dalam mengukur kepuasan pelanggan secara universal yaitu;

(1) Attributes related to product yaitu dimensi kepuasan yang berkaitan dengan atribut dari produk seperti penetapan nilai yang didapatkan dengan harga, kemampuan produk menentukan kepuasan, benefit dari produk tersebut.

(2) Attributes related to service yaitu dimensi kepuasan yang berkaitan dengan atribut dari pelayanan misalnya dengan garansi yang dijanjikan, proses pemenuhan pelayanan atau pengiriman, dan proses penyelesaian masalah yang diberikan. 


\section{JURNAL ORGANISASI DAN MANAJEMEN}

Volume 3 (September, 2015)

(3) Attributes related to purchase yaitu dimensi kepuasan yang berkaitan dengan atribut dari keputusan untuk membeli atau tidaknya dari produsen seperti kemudahan mendapat informasi, kesopanan karyawan dan juga pengaruh reputasi perusahaan

4. Minat Beli Ulang

Minat beli merupakan bagian dari komponen perilaku dalam sikap mengkonsumsi. Menurut Kinnear dan Taylor (1995 : 306, dalam Saidani dan Arifin, 2012), minat beli adalah tahap kecenderungan responden untuk bertindak sebelum keputusan membeli benarbenar dilaksanakan. Minat membeli ulang yang tinggi mencerminkan tingkat kepuasan yang tinggi dari konsumen ketika memutuskan untuk mengkonsumsi produk yang diberikan setelah mencoba produk tersebut dan kemudian timbul rasa suka atau tidak suka terhadap produk (Sundalangi dkk., 2014).

Menurut Ferdinand (2002:25-26, dalam Saidani dan Arifin, 2012) minat beli ulang dapat diidentifikasi melalui indikator-indikator sebagai berikut:

1. Minat transaksional yaitu kecenderungan seseorang untuk selalu membeli ulang produk yang telah dikonsumsinya.

2. Minat referensial yaitu kecenderungan seseorang untuk mereferensikan produk yang sudah dibelinya, agar juga dibeli oleh orang lain, dengan referensi pengalaman konsumsinya.

3. Minat preferensial yaitu minat yang menggambarkan perilaku seseorang yang selalu memiliki preferensi utama pada produk yang telah dikonsumsi. Preferensi ini hanya dapat diganti bila terjadi sesuatu dengan produk preferensinya.

4. Minat eksploratif, minat ini menggambarkan perilaku seseorang yang selalu mencari informasi mengenai produk yang diminatinya dan mencari informasi untuk mendukung sifat-sifat positif dari produk yang dilanggananinya.

Dalam menjelaskan pengaruh antar variable yang dianalisis dalam penelitian ini mengacu pada teori kontrol pribadi (personal control theory), menjelaskan bahwa kepuasan didasarkan pada pengalaman hidup seseorang atau pekerjaan berhubungan dengan persepsi melalui perbandingan psikologis antara tindakan dan hasil yang diinginkan (Rotter,1966; dalam Rahma, 2007). Dimana kecenderungan konsumen untuk melakukan pembelian ulang disebabkan karena tingginya kepuasan yang dimiliki oleh konsumen dan tingginya kualitas layanan yang dirasakan serta tingginya kualitas produk yang digunakan oleh konsumen (Puspitasari, 2006; Rahma, 2007; Saidani dan Arifin, 2012).

\section{Metode Penelitian}

Pendekatan yang dilakukan dalam penelitian ini adalah pendekatan kuantitatif melalui explanatory survey, Menurut Sugiyono, (2013:13) explanatory survey merupakan penelitian yang mengambil sampel dari suatu populasi yang diteliti dan menjelaskan hubungan klasual antara variable-variabel yang akan melalui pengujian hipotesis.

Populasi pada penelitian ini adalah seluruh konsumen pada McDonald's Alauddin Makassar yang jumlahnya sangat banyak dan tidak dapat teridentifikasi, dikarenakan jumlah populasi yang sangat besar dan tidak dapat di identifikasi maka penentuan sample dilakukan dengan cara menggunakan insidental sampling yaitu 


\section{JURNAL ORGANISASI DAN MANAJEMEN}

Volume 3 (September, 2015)

teknik penentuan sampel berdasarkan kebetulan, dimana siapa saja yang secara kebetulan/incidental bertemu dengan peneliti dapat digunakan sebagai sampel, bila dipandang orang kebetulan ditemui itu cocok sebagai sumber data (Sugiyono, 2013 : 122). Insidental sampling dilakukan dengan batasan waktu yang telah ditentukan selama dua minggu. Sampel dalam penelitian ini adalah konsumen yang sudah melakukan pembelian secara berulang atau konsumen lama.

\section{Hasil Penelitian}

1. Karakteristik responden

a. Tingkat pengembalian kuesioner

Kuesioner yang didistribusikan sebanyak 100 kuesioner, tabelberikut ini menggambarkan tingkat pengembalian dan pengolahan kuesioner dalam penelitian ini.

Tabel 1. Tingkat Pengembalian Kuesioner

\begin{tabular}{|c|l|c|c|c|}
\hline NO. & \multicolumn{1}{|c|}{ Keterangan } & Jumlah & Persentase & Total \\
\hline 1. & $\begin{array}{l}\text { Jumlah kuesioner yang } \\
\text { kembali }\end{array}$ & 100 & $100 \%$ & $\begin{array}{c}\text { Total Penyebaran } \\
100 \text { Kuesioner }\end{array}$ \\
\hline 2. & $\begin{array}{l}\text { Jumlah kuesioner yang } \\
\text { dapat diolah }\end{array}$ & 80 & $80 \%$ & $\begin{array}{c}\text { Total } \\
\text { Pendistribusian } \\
100 \text { Kuesioner }\end{array}$ \\
\hline 3. & $\begin{array}{l}\text { Jumlah kuesioner yang } \\
\text { cacat }\end{array}$ & 20 & $20 \%$ & \\
\hline
\end{tabular}

Berdasarkan 100 kuesioner yang disebarkan dan yang kembali sebanyak $100 \%$ atau 100 kuesioner. Kuesioner yang dapat diolah sebanyak $80 \%$ atau 80 kuesioner. Kuesioner yang tidak dapat diolah karena tidak memenuhi kriteria sebagai sampel dan tidak diisi secara lengkap oleh responden sebanyak $20 \%$ atau 20 kuesioner.

\section{b. Distribusi responden}

Hasil uji deskripsi responden berdasarkan jenis kelamin yang menunjukkan bahwa 43 orang atau 56\% responden didominasi oleh jenis kelamin wanita dan sisanya sebanyak 37 orang atau 44\% responden berjenis kelamin pria. Bahwa berdasarkan faktualnya pria lebih banyak makan dibandingkan dengan perempuan tetapi dalam hal ini wanita lebih cenderung beradadi McDonald's dikarenakan kegemaran wanita yang suka untuk menghabiskan waktu ditempat makan. Hasil uji deskripsi responden berdasarkan umur yang dicirikan melalui : 15-24 Tahun sebanyak 60 orang atau sebesar 75\%, 25-34 Tahun sebanyak 15 orang atau sebesar $19 \%$ dan 35-44 Tahun sebanyak 5 orang atau sebesar $6 \%$. Bahwa usia remaja cenderung lebih dominan berada pada McDonald's dikarenakan kegemaran remaja yang suka menghabiskan waktu bersama di tempat makan untuk sekedar makan, minum dan berbincang-bincang.

Hasil uji deskripsi responden berdasarkan lamanya konsumen mengkonsumsi yang dicirikan melalui : 0 Tahun sebanyak 0 orang atau sebesar $0 \%$, $<2$ Tahun sebanyak 32 orang atau sebesar $40 \%$, $>2$ Tahun sebanyak 25 orang atau sebesar $31 \%$ dan $<4$ Tahun sebanyak 23 orang atau sebesar 29\%. Bahwa dimana tingkat persaingan franchise semakin tinggi sehingga banyaknya perusahaan frinchise yang menjadi pilihan yang mengakibatkan konsumen yang mengkonsumsi hanya $<2$ tahun. Hasil uji deskripsi responden berdasarkan pekerjaan yang 


\section{JURNAL ORGANISASI DAN MANAJEMEN}

Volume 3 (September, 2015)

dicirikan melalui : pelajar/mahasiswa sebanyak 57 orang atau sebesar $71 \%$, karyawan sebanyak 18 orang atau sebesar 23\% dan ibu rumah tangga sebanyak 5 orang atau sebesar 6\%. Bahwa para remaja yang berprofesi mahasiswa/pelajar yang dominan berada di McDonald's dikarenakan kegemaran para remeja yang suka menghabiskan waktu bersama di tempat makan untuk sekedar makan, minum dan berbincang-bincang.

\section{Deskripsi Variabel Penelitian}

a. Tanggapan Responden untuk variabel kualitas produk

Variabel kualitas produk dicirikan melalui rasa yang enak dengan nilai rerata tanggapan responden sebesar 3.98\%. kondisi tersebut disebabkan karena pernyataan di dalam indikator yaitu informasi yang didapatkan konsumen terhadap menu makanan dan minuman yang disajikan secara lengkap dengan nilai rerata sebesar $4.04 \%$. Rerata tanggapan responden tertinggi berikutnya ditunjukkan melalui indikator fitur produk sebanyak 3.72\%, hal ini dikarenakan pada pernyataan bahwa ketertarikan konsumen dengan menu makanan dan minuman yang ditawarkan oleh McDonald's dengan nilai rerata sebesar 3.85\%. Rerata tanggapan responden yang terendah yaitu indikator daya tahan sebesar 3.45\%, kondisi tersebut ditunjukkan pada pernyataan yang terendah yaitu produk makanan dan minuman yang ditawarkan kepada konsumen merupakan produk yang memiliki daya tahan yang tinggi dengan nilai rerata sebesar 3.36\%.

b. Tanggapan Responden untuk variabel kualitas pelayanan.

Variabel kualitas pelayanan dicirikan melalui bukti fisik (tangibles) dengan nilai rerata tanggapan responden sebesar 4.16\%. kondisi tersebut disebabkan karena pernyataan di dalam indikator yaitu karyawan McDonald's berpakaian yang serasi, bersih, dan rapih dengan nilai rerata sebesar $4.20 \%$. Rerata tanggapan responden tertinggi berikutnya ditunjukkan melalui indikator daya tangkap (responsive) sebesar 3.78\%, hal ini dikarenakan pada pernyataan bahwa karyawan McDonald's memberikan layanan dengan cepat dengan rerata responden sebesar 3.83\%. Disusul dengan indikator keandalan (realibility) dengan rerata tanggapan responden sebesar $3.69 \%$, hal ini dikarenakan pada pernyataan bahwa konsumen sangat terpuaskan dengan menu produk makanan dan minuman yang ditawarkan oleh McDonald's dengan rerata tanggapan responden sebesar 3.86\%.

Pada indikator jaminan (assurance), rerata tanggapan responden sebesar $3.59 \%$, kondisi tersebut dikarenakan pada pernyataannya yaitu karyawan McDonald's dapat menjawab pertanyaan dari konsumen dengan baik dengan rerata tanggapan responden sebesar 3.78\%. Rerata tanggapan responden yang terendah di buktikan pada variabel dukungan (emphaty) yaitu sebesar 3.21\%. kondisi tersebut ditunjukkan pada pernyataan yang terendah yaitu karyawan McDonald's membuat konsumen merasa spesial dengan rerata responden sebesar 3.04\%.

c. Tanggapan Responden untuk variabel kepuasan konsumen.

Variabel kepuasan konsumen dicirikan melalui atribut produk (attribute related to product) dengan nilai rerata tanggapan responden sebesar $3.77 \%$. kondisi tersebut disebabkan karena pernyataan di dalam indikator yaitu apabila konsumen dapat melakukan pembelian lagi, maka konsumen akan membeli produk yang berbeda dengan nilai rerata sebesar $3.80 \%$. Rerata tanggapan responden tertinggi 


\section{JURNAL ORGANISASI DAN MANAJEMEN}

Volume 3 (September, 2015)

berikutnya ditunjukkan melalui indikator atribut keputusan (attribute related to purchase) sebesar 3.73\%, hal ini dikarenakan pada pernyataan bahwa konsumen merasa puas dengan keputusannya untuk membeli produk yang dimiliki oleh McDonald's dengan nilai rerata sebesar 3.75\%. Rerata tanggapan responden yang terendah yaitu indikator atribut layanan (attribute related to service) sebesar 3.54\%, kondisi tersebut ditunjukkan pada pernyataan yang terendah yaitu McDonald's merupakan salah satu layanan yang terbaik didapatkan oleh konsumen dengan nilai rerata sebesar $3.30 \%$.

d. Tanggapan Responden untuk variabel minat beli ulang.

Variabel minat beli ulang dicirikan melalui minat eksploratif dengan nilai rerata tanggapan responden sebesar 3.49\%. kondisi tersebut disebabkan karena pernyataan di dalam indikator yaitu konsumen akan merekomendasikan produk makanan dan minuman yang difavoritkannya agar tetap dipertahankan dalam daftar menu di McDonald's dengan nilai rerata sebesar 3.55\%. Rerata tanggapan responden tertinggi berikutnya ditunjukkan melalui indikator minat referensial sebanyak 3.30\%, hal ini dikarenakan pada pernyataan bahwa konsumen senantiasa akan merekomendasikan menu makanan dan minuman yang baru dan berkualitas kepada orang lain. Pada indikator minat transaksional, rerata tanggapan responden sebesar $3.26 \%$, kondisi tersebut dikarenakan pada pernyataannya yaitu McDonald's membuat konsumennya ketagihan dengan menu makanan dan minuman yang ada dengan rerata tanggapan responden sebesar 3.29\%. rerata tanggapan responden yang terendah di buktikan pada variabel minat preferensial yaitu sebesar $3.23 \%$. Kondisi tersebut ditunjukkan pada pernyataan yang terendah yaitu McDonald's selalu menjadi pilihan utama konsumen dengan rerata tanggapan responden sebesar $2.86 \%$.

\section{Hasil Penelitian}

Analisis jalur adalah suatu teknik untuk menganalisis hubungan sebab akibat yang terjadi pada regresi berganda jika variabel eksogennya (independen) mempengaruhi variabel endogen (dependent) tidak hanya secara langsung, tetapi juga secara tidak langsung, yang terdiri atas pengaruh langsung dan tidak langsung. Untuk mendapatkan nilai pengaruh langsung dan tidak langsung digunakan analisis regresi dengan variabel intervening. Variabel intervening merupakan variabel antara atau mediating, yang berfungsi memediasi hubungan antara variabel eksogen dengan variabel endogenn (Robert D. Rutherford; dalam Jonathan Sarwono, 2007:1).

Tabel 2. Hasil Analisis Jalur

\begin{tabular}{|c|c|c|c|c|c|c|}
\hline \multicolumn{7}{|c|}{ Coefficients $^{a}$} \\
\hline \multirow[b]{2}{*}{ Model } & & \multicolumn{2}{|c|}{$\begin{array}{c}\text { Unstandardized } \\
\text { Coefficients }\end{array}$} & \multirow{2}{*}{$\begin{array}{c}\begin{array}{c}\text { Standardized } \\
\text { Coefficients }\end{array} \\
\text { Beta }\end{array}$} & \multirow[b]{2}{*}{$\mathrm{t}$} & \multirow[b]{2}{*}{ Sig. } \\
\hline & & $\mathrm{B}$ & Std. Error & & & \\
\hline \multirow[t]{3}{*}{1} & (Constant) & -.086 & .358 & & -.240 & .811 \\
\hline & K. PRODUK & .250 & .105 & .222 & 2.384 & .020 \\
\hline & K. PELAYANAN & .770 & .117 & .613 & 6.592 & .000 \\
\hline
\end{tabular}


Volume 3 (September, 2015)

Pada tabel 2 terlihat bahwa nilai standardized coefficients yang merupakan koefisien jalur variabel kualitas produk (X1) dan kualitas layanan (X2). Dari tabel diatas dapat disusun matriks koefisien jalur sebagai berikut :

Tabel 3. Koefisien Determinasi $\left(\mathrm{R}^{2}\right)$

$$
\left(\begin{array}{ll}
1 & 1 \\
1 & 2
\end{array}\right)=\left(\begin{array}{l}
0.222 \\
0.613
\end{array}\right)
$$

\begin{tabular}{|l|r|r|r|r|}
\hline \multicolumn{5}{|c|}{ Model Summary } \\
\hline Model & $\mathrm{R}$ & $\mathrm{R}$ Square & $\begin{array}{c}\text { Adjusted } \\
\text { R Square }\end{array}$ & $\begin{array}{r}\text { Std. Error of } \\
\text { the Estimate }\end{array}$ \\
\hline 1 & $.772^{\mathrm{a}}$ & .595 & .585 & .36193 \\
\hline a. Predictors: (Constant), K. PELAYANAN, K. PRODUK \\
b. Dependent Variable: KEPUASAN \\
Sumber: Output SPSS 21.0 for window
\end{tabular}

Pada tabel 3 terlihat bahwa R Square atau koefisien determinasi yaitu 0.595. Secara manual R Square dapat dihitung dengan mengubah matriks koefisien jalur X1 dan X2 menjadi matriks baris lalu memperkalikannya dengan matriks kolom Y1. Dari R Square tersebut dapat dihitung koefisien jalur variabel lain diluar model yaitu $\rho Y_{1 \varepsilon}$ dengan rumus :

1) Koefisien Jalur $\rho Y_{1} X_{1}$

$$
\rho Y 1 \varepsilon=\sqrt{1-0.595=0.6363}
$$

$$
\begin{aligned}
& \mathrm{H}_{\mathrm{o}}: \rho \mathrm{Y}_{1} \mathrm{X}_{1}=0 \\
& \mathrm{H}_{1}: \rho \mathrm{Y}_{1} \mathrm{X}_{1} \neq 0
\end{aligned}
$$

Pada tabel 4.15 (kolom sign) $=0.020$ yang lebih kecil dari 0.005 atau pada kolom $\mathrm{t}=2.384$ yang lebih besar dari titik kritis 2.376. Dengan demikian $\mathrm{H}_{\mathrm{o}}$ ditolak.

2) Koefisien Jalur $\rho \mathrm{Y}_{1} \mathrm{X}_{2}$

$$
\begin{aligned}
& \mathrm{H}_{\mathrm{o}}: \rho \mathrm{Y}_{1} \mathrm{X}_{2}=0 \\
& \mathrm{H}_{1}: \rho \mathrm{Y}_{1} \mathrm{X}_{2} \neq 0
\end{aligned}
$$

Pada tabel 2 (kolom sign) $=0.000$ yang lebih kecil dari 0.005 atau pada

\begin{tabular}{|c|c|c|c|c|c|}
\hline \multicolumn{6}{|c|}{ Coefficients $^{a}$} \\
\hline \multirow[b]{2}{*}{ Model } & & \multicolumn{2}{|c|}{$\begin{array}{l}\text { Unstandardized } \\
\text { Coefficients }\end{array}$} & \multirow{2}{*}{$\begin{array}{c}\text { Standardized } \\
\text { Coefficients } \\
\text { Beta }\end{array}$} & \multirow[b]{2}{*}{ Sig. } \\
\hline & & $\mathrm{B}$ & Std. Error & & \\
\hline \multirow[t]{4}{*}{1} & (Constant) & .302 & .401 & & .455 \\
\hline & K. PRODUK & .012 & .121 & .011 & .921 \\
\hline & K. PELAYANAN & .342 & .164 & .273 & .040 \\
\hline & KEPUASAN & .467 & .128 & .468 & .000 \\
\hline
\end{tabular}
kolom $\mathrm{t}=6.592$ yang lebih besar dari titik kritis 3.421. Dengan demikian $\mathrm{H}_{\mathrm{o}}$ ditolak

Dari hasil pengujian koefisien jalur dapat disimpulkan bahwa koefisien jalur dari X1 ke Y1 dan X2 ke Y1, kedua-duanya secara statistik adalah signifikan ( $t_{\text {hitung }}$ lebih besar dari $t_{\text {tabel }}$ dan tingkat signifikan lebih kecil dari 0.005).

Tabel 4. Hasil Analisis Jalur

Pada table 4 terlihat bahwa nilai standardized coefficients yang merupakan koefisien jalur variabel kualitas produk (X1),kualitas layanan (X2) dan kepuasan (Y1). Dari tabel diatas dapat disusun matriks koefisien jalur sebagai berikut :

$$
\begin{aligned}
& \begin{array}{lll}
2 & 1 & 0.011
\end{array} \\
& \text { ( } \left.\begin{array}{ll}
2 & 2
\end{array}\right)=(0.273) \\
& \begin{array}{lll}
2 & 1 & 0.468
\end{array}
\end{aligned}
$$


Volume 3 (September, 2015)

Tabel 5. Koefisien Determinasi $\left(\mathrm{R}^{2}\right)$

\begin{tabular}{|c|c|c|c|c|}
\hline \multicolumn{5}{|c|}{ Model Summary ${ }^{\mathrm{b}}$} \\
\hline Model & $\mathrm{R}$ & R Square & $\begin{array}{l}\text { Adjusted } \\
\mathrm{R} \text { Square }\end{array}$ & $\begin{array}{c}\text { Std. Error of the } \\
\text { Estimate }\end{array}$ \\
\hline 1 & $.704^{\mathrm{a}}$ & .496 & .476 & .40510 \\
\hline \multicolumn{5}{|c|}{ a. Predictors: (Constant), KEPUASAN, K. PRODUK, K. PELAYANAN } \\
\hline \multicolumn{5}{|c|}{ b. Dependent Variable: MINAT BELI } \\
\hline \multicolumn{5}{|c|}{ Sumber: Output SPSS 21.0 for window } \\
\hline
\end{tabular}

Pada tabel 5 terlihat bahwa R Square atau koefisien determinasi yaitu 0.496 . Secara manual R Square dapat dihitung dengan mengubah matriks koefisien jalur $\mathrm{X} 1, \mathrm{X} 2$ dan Y1 menjadi matriks baris lalu memperkalikannya dengan matriks kolom Y2. Dari R Square tersebut dapat dihitung koefisien jalur variabel lain diluar model yaitu $\rho Y_{2 \varepsilon}$ dengan rumus :

1) Koefisien Jalur $\rho Y_{2} X_{1}$

$$
\rho Y 2 \varepsilon=\sqrt{1-0.496=0.7099}
$$

$$
\begin{aligned}
& \mathrm{H}_{\mathrm{o}}: \rho \mathrm{Y}_{2} \mathrm{X}_{1}=0 \\
& \mathrm{H}_{1}: \rho \mathrm{Y}_{2} \mathrm{X}_{1} \neq 0
\end{aligned}
$$

Pada tabel 4.19 (kolom sign) $=0.921$ yang lebih besar dari 0.005 atau pada kolom $\mathrm{t}=0.100$ yang lebih kecil dari titik kritis 1.293. Dengan demikian $\mathrm{H}_{1}$ diterima.

2) Koefisien Jalur $\rho \mathrm{Y}_{2} \mathrm{X}_{2}$

$$
\begin{aligned}
& \mathrm{H}_{\mathrm{o}}: \rho \mathrm{Y}_{2} \mathrm{X}_{2}=0 \\
& \mathrm{H}_{1}: \rho \mathrm{Y}_{2} \mathrm{X}_{2} \neq 0
\end{aligned}
$$

Pada tabel 4.19 (kolom sign) $=0.040$ yang lebih kecil dari 0.005 atau pada kolom $\mathrm{t}=2.090$ yang lebih kecil dari titik kritis 2.642. Dengan demikian $\mathrm{H}_{\mathrm{o}}$ ditolak.

3) Koefisien Jalur $\rho \mathrm{Y}_{2} \mathrm{Y}_{1}$

$$
\begin{aligned}
& \mathrm{H}_{\mathrm{o}}: \rho \mathrm{Y}_{2} \mathrm{X}_{2}=0 \\
& \mathrm{H}_{1}: \rho \mathrm{Y}_{2} \mathrm{X}_{2} \neq 0
\end{aligned}
$$

Pada tabel 4.19 (kolom sign) $=0.000$ yang lebih kecil dari 0.005 atau pada kolom $\mathrm{t}=3.659$ yang lebih kecil dari titik kritis 3.423. Dengan demikian $\mathrm{H}_{\mathrm{o}}$ ditolak .

Dari hasil pengujian koefisien jalur dapat disimpulkan bahwa koefisien jalur dari X1 ke Y2 tidak signifikan ( $t_{\text {hitung }}$ lebih kecil dari $t_{\text {tabel }}$ dan tingkat signifikan lebih besar dari 0.005). oleh karna itu proses akan diulang dengan mengeluarkan X1 dari model. Sedangkan koefisien jalur X2 ke Y2 dan Y1 ke Y2 signifikan ( $t_{\text {hitung }}$ lebih kecil dari tabel dan tingkat signifikan lebih besar dari 0.005).

Gambar 1. Diagram Jalur

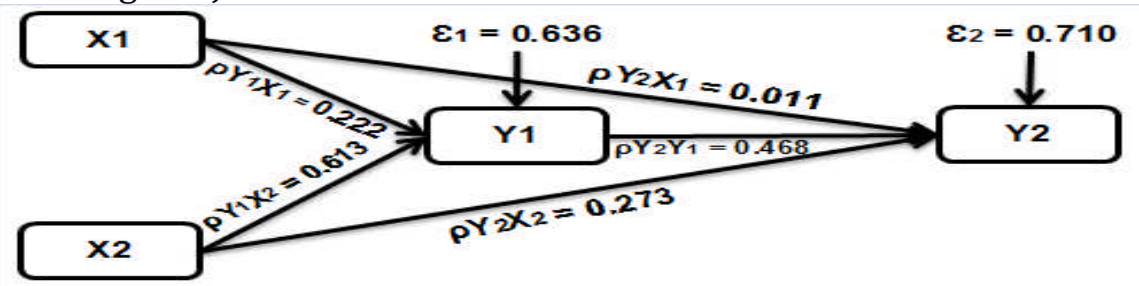

\section{4) Metode Trimming}

Jika ada variabel eksogen yang tidak signifikan maka perlu diperbaiki dengan menggunakan metode trimming. Metode trimming yaitu mengeluarkan variabel eksogen yang tidak signifikan dari analisisnya, kemudian diuji ulang dimana variabel eksogen yang tidak signifikan tidak diikut sertakan (Adiningrum dkk, 2013).

Halaman 24

Author : Arfiani Bahar \& Herman Sjaharuddin (14-34)

Volume 3 (September, 2015) https://dx.doi.org/10.17605/OSF.IO/TC2FE 
Volume 3 (September, 2015)

Tabel 6. Hasil Analisis Jalur

\begin{tabular}{|c|c|c|c|c|c|c|}
\hline \multicolumn{7}{|c|}{ Coefficients $^{\mathrm{a}}$} \\
\hline \multirow[b]{2}{*}{ Model } & & \multicolumn{2}{|c|}{$\begin{array}{l}\text { Unstandardized } \\
\text { Coefficients }\end{array}$} & \multirow{2}{*}{$\begin{array}{c}\begin{array}{c}\text { Standardized } \\
\text { Coefficients }\end{array} \\
\text { Beta } \\
\end{array}$} & \multirow[b]{2}{*}{ t } & \multirow[b]{2}{*}{ Sig. } \\
\hline & & $B$ & Std. Error & & & \\
\hline \multirow[t]{3}{*}{1} & (Constant) & .315 & .377 & & .836 & .406 \\
\hline & K. PELAYANAN & .347 & .154 & .277 & 2.260 & .027 \\
\hline & KEPUASAN & .470 & .122 & .472 & 3.843 & .000 \\
\hline
\end{tabular}

Pada tabel 6. terlihat bahwa nilai standardized coefficients yang merupakan koefisien jalur variabel kualitas layanan (X2) dan kepuasan (Y1). Dari tabel diatas dapat disusun matriks koefisien jalur sebagai berikut :

$$
\left(\begin{array}{ll}
2 & 2 \\
2 & 1
\end{array}\right)=\left(\begin{array}{l}
0.277 \\
0.472
\end{array}\right)
$$

Berdasarkan pengujian, hanya koefisien jalur dari X1 ke Y1, X2 ke Y1, X2 ke Y2 dan Y1 ke Y2 yang signifikan, sedangkan X1 ke Y2 tidak signifikan. Dari hasil yang didapatkan ditarik kesimpulan bahwa yang berpengaruh terhadap kepuasan konsumen yaitu kualitas produk dan kualitas pelayanan. Sedangkan minat beli ulang berpengaruh terhadap kualitas pelayanan dan kepuasan, dan kualitas produk tidak signifikan terhadap minat beli ulang $(0.921>0.005)$. Dengan demikian dilakukan perhitungan ulang dengan tidak memasukkan kualitas produk. Sehingga dapat digambarkan diagram jalurnya sebagai berikut :

Gambar 2. Diagram Jalur

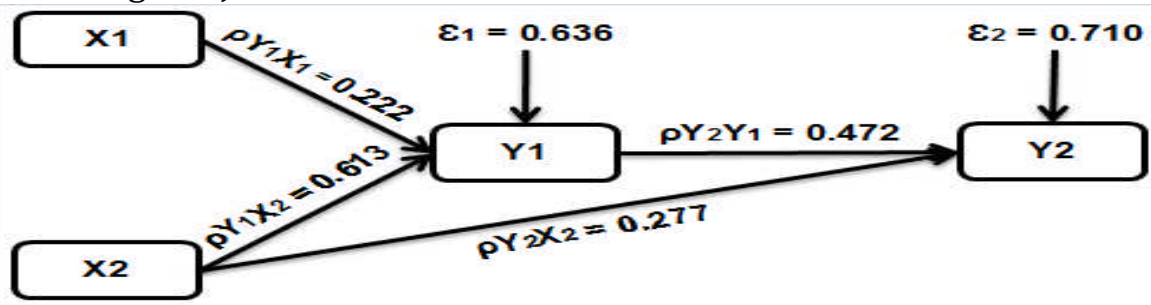

Dengan persamaan jalur stuktural :

$$
\begin{aligned}
& 1=0.222+0.613+0.636 \\
& 2=0.277+0.472+0.710
\end{aligned}
$$

Variabel mediasi atau variabel tidak langsung :

1. Pengaruh kualitas produk (X1) terhadap minat beli ulang (Y2) melalui kepuasan (Y1), yaitu :

$$
1 \rightarrow 1 \rightarrow 2=0.222 \times 0.472=0.105
$$

2. Pengaruh kualitas pelayanan (X2) terhadap minat beli ulang (Y2) melalui kepuasan (Y1), yaitu :

$$
2 \rightarrow 1 \rightarrow 2=0.613 \times 0.472=0.289
$$

5) Uji Model (Uji-F)

Pengujian ini dilakukan untuk mengetahui model yang dibangun memenuhi kelayakan dari suatku model. Pengujian yang dilakukan menggunakan uji distribusi F caranya, yakni dengan membandingkan antara nilai kritis ( ) dengan ( $h \quad$ ) yang terdapat pada tabel Analysis of Variance dari hasil perhitungan. Pada derajat signifikan $95 \%(\alpha=0,05)$ (Sugiyono, 2013)

Author : Arfiani Bahar \& Herman Sjaharuddin (14-34)

Halaman 25

Volume 3 (September, 2015) https://dx.doi.org/10.17605/OSF.IO/TC2FE 
Volume 3 (September, 2015)

Tabel 7. Hasil Uji Model 1 (Uji-F)

\begin{tabular}{|c|c|c|c|c|c|c|}
\hline \multicolumn{7}{|c|}{ ANOVA $^{\mathrm{a}}$} \\
\hline \multicolumn{2}{|l|}{ Model } & $\begin{array}{c}\text { Sum of } \\
\text { Squares }\end{array}$ & df & Mean Square & $\mathrm{F}$ & Sig. \\
\hline \multirow[t]{3}{*}{1} & Regression & 14.847 & 2 & 7.424 & 56.670 & $.000^{\circ}$ \\
\hline & Residual & 10.087 & 77 & .131 & & \\
\hline & Total & 24.934 & 79 & & & \\
\hline \multicolumn{7}{|c|}{ a. Dependent Variable: KEPUASAN } \\
\hline \multicolumn{7}{|c|}{ b. Predictors: (Constant), K. PELAYANAN, K. PRODUK } \\
\hline \multicolumn{7}{|c|}{ Sumber: Output SPSS 21.0 for window } \\
\hline
\end{tabular}

Dari tabel diatas uji F dapat dirumuskan df1 = jumlah variabel (eksogen dan endogen) - variabel bebas dan df2 $=$ jumlah responden - jumlah variabel (dependen dan independen). Jadi, df1 $=3-1=2$ dan df $2=80-3=77$ atau yang disebut dengan nilai residual. Maka Ftabel diperoleh pada lampiran yaitu 3.97. Tabel 7. menunjukkan bahwa hasil uji $\mathrm{F}$ yaitu fhitung>ftabel $(56.670>3.97)$ dan nilai signifkan sebesar 0,000 . Hal ini berarti bahwa model yang digunakan memenuhi goodness of fit model.

Tabel 8. Hasil Uji Model 2 (Uji F)

\begin{tabular}{|c|c|c|c|c|c|}
\hline \multicolumn{6}{|c|}{ ANOVA* } \\
\hline Model & $\begin{array}{l}\text { Sum of } \\
\text { Squares }\end{array}$ & df & $\begin{array}{c}\text { Mean } \\
\text { Square }\end{array}$ & $\mathrm{F}$ & Sig. \\
\hline 1 Regression & 12.285 & 3 & 4.095 & 24.954 & $.000^{\mathrm{s}}$ \\
\hline Residual & 12.472 & 76 & .164 & & \\
\hline Total & 24.758 & 79 & & & \\
\hline
\end{tabular}

Tabel 8 menunjukkan bahwa hasil uji F yaitu fhitung>ftabel $(24.954>3.97)$ dan nilai signifkan sebesar 0,000. Hal ini berarti seluruh variabel independen, yaitu kualitas produk dan kualitas pelayanan secara simultan memiliki pengaruh terhadap minat beli.

6) Uji Parsial (Uji-T)

Uji-t digunakan untuk mengetahui seberapa jauh pengaruh satu variabel penjelas secara individual dalam menerangkan variasi variabel terikat.Pengujian melauli uji-t adalah dengan thitung dan ttabel pada derajat signifikasi $95 \%$ ( $\alpha=$ 0,05 ) dengan pengujian dua sisi.

Tabel 9. Hasil Uji Parsial 1 (Uji t)

\begin{tabular}{|c|c|c|c|c|c|c|}
\hline \multicolumn{7}{|c|}{ Coefficients $^{a}$} \\
\hline \multirow[b]{2}{*}{ Model } & & \multicolumn{2}{|c|}{$\begin{array}{l}\text { Unstandardized } \\
\text { Coefficients }\end{array}$} & \multirow{2}{*}{\begin{tabular}{|c|}
$\begin{array}{c}\text { Standardized } \\
\text { Coefficients }\end{array}$ \\
Beta
\end{tabular}} & \multirow[b]{2}{*}{$t$} & \multirow[b]{2}{*}{ Sig. } \\
\hline & & $\mathrm{B}$ & Std. Error & & & \\
\hline \multirow[t]{3}{*}{1} & (Constant) & -.086 & .358 & & -.240 & .811 \\
\hline & K. PRODUK & .250 & .105 & .222 & 2.384 & .020 \\
\hline & K. PELAYANAN & .770 & .117 & .613 & 6.592 & .000 \\
\hline
\end{tabular}

Berdasarkan tabel 9 diatas dapat dilihat yaitu pada nilai t dengan nilai $\mathrm{df}=\mathrm{n}-$ $\mathrm{k}-1=80-2-1=77$, maka diperoleh pada lampiran yaitu 2.641 dan 3,421. Pada tabel diatas menunjukkan hasil bahwa variabel kualitas produk dengan nilai thitung lebih besar dari ttabel $(2.384>2.641)$ dan tingkat signifikan lebih kecil dari 0.05 $(0.020<0.05)$, yang berarti H1 diterima sehingga dapat dikatakan bahwa kualitas produk berpengaruh signifikan secara parsial terhadap kepuasan. Sedangkan variabel kualitas pelayanan dengan nilai thitung lebih besar dari t-tabel (6.592 >

Author : Arfiani Bahar \& Herman Sjaharuddin (14-34)

Halaman 26

Volume 3 (September, 2015) https://dx.doi.org/10.17605/OSF.IO/TC2FE 
Volume 3 (September, 2015)

3,421) dan nilai signifikan lebih kecil dari $0.05(0.000<0.05)$, maka dapat disimpulkan bahwa $\mathrm{H}_{2}$ diterima yang berarti kualitas pelayanan berpengaruh signifikan secara parsial terhadap kepuasan.

Tabel 10. Hasil Uji Parsial 2 (Uji-t)

\begin{tabular}{|c|c|c|c|c|c|c|}
\hline \multicolumn{7}{|c|}{ Coefficients ${ }^{a}$} \\
\hline \multirow[b]{2}{*}{ Model } & & \multicolumn{2}{|c|}{$\begin{array}{l}\text { Unstandardized } \\
\text { Coefficients }\end{array}$} & \multirow{2}{*}{$\begin{array}{c}\begin{array}{c}\text { Standardized } \\
\text { Coefficients }\end{array} \\
\text { Beta }\end{array}$} & \multirow[b]{2}{*}{$t$} & \multirow[b]{2}{*}{ Sig. } \\
\hline & & $\mathrm{B}$ & Std. Error & & & \\
\hline \multirow[t]{4}{*}{1} & (Constant) & .302 & .401 & & .752 & .455 \\
\hline & K. PRODUK & .012 & .121 & .011 & .100 & .921 \\
\hline & K. PELAYANAN & .342 & .164 & .273 & 2.090 & .040 \\
\hline & KEPUASAN & .467 & .128 & .468 & 3.659 & .000 \\
\hline
\end{tabular}

Berdasarkan tabel 10 diatas dapat dilihat yaitu pada nilai t dengan nilai $\mathrm{df}=$ $\mathrm{n}-\mathrm{k}-1=80-3-1=76$, maka diperoleh pada lampiran yaitu 1.293, 2.642 dan 3,423 . Pada tabel diatas menunjukkan hasil bahwa variabel kualitas produk dengan nilai thitung lebih kecil dari ttabel $(0.100<1.991)$ dan tingkat signifikan lebih besar dari 0.05 (0.921 > 0.05), yang berarti $\mathrm{H} 1$ tidak diterima sehingga dapat dikatakan bahwa kualitas produk tidak berpengaruh signifikan secara parsial terhadap minat beli ulang. Sedangkan variabel kualitas pelayanan dengan nilai thitung lebih kecil dari ttabel $(2.090<2.642)$ dan nilai signifikan lebih kecil dari $0.05(0.040<0.05)$, maka dapat disimpulkan bahwa $\mathrm{H}_{2}$ diterima yang berarti kualitas pelayanan berpengaruh signifikan secara parsial terhadap minat beli ulang. Dan variabel kepuasan dengan nilai thitung lebih besar dari ttabel(3.659> 3.423) dan nilai signifikan lebih kecil dari $0.05(0.000<0.05)$, maka dapat disimpulkan bahwa $\mathrm{H}_{3}$ diterima yang berarti kepuasan berpengaruh signifikan secara parsial terhadap minat beli ulang

\section{Interprestasi Hasil Penelitian}

a. Pengaruh kualitas produk terhadap kepuasan konsumen

Hasil penelitian ini menyatakan bahwa kualitas produk berpengaruh signifikan secara parsial terhadap kepuasan konsumen. Hal ini terbukti bahwa thitung lebih besar dari t-tabel $(2.384>2.376)$ dan tingkat signifikan lebih kecil dari $0.05(0.020<0.05)$. Hal ini membuktikan bahwa dengan adanya kualitas produk yang tinggi dapat meningkatkankan kepuasan konsumen yang tinggi. Hasil penelitian sejalan dengan penelitian Resty Avita Haryanto (2013) yang menunjukkan bahwa kualitas produk berpengaruh positif dan signifikan terhadap kepuasan pelanggan. Hal ini menunjukkan bahwa kualitas produk yang tinggi dapat meningkatkan kepuasan konsumen. Hasil tidak sejalan dengan penelitian Rizan dan Andika (2011) yang menyatakan bahwa kualitas produk tidak berpengaruh terhadap kepuasan.

\section{b. Pengaruh kualitas pelayanan terhadap kepuasan konsumen}

Hasil penelitian ini menyatakan bahwa kualitas pelayanan berpengaruh signifikan secara parsial terhadap kepuasan konsumen. Hal ini terbukti bahwa thitung lebih besar dari t-tabel $(6.592>3,421)$ dan tingkat signifikan lebih kecil dari $0.05(0.000<0.05)$. Hal ini membuktikan bahwa dengan adanya kualitas pelayanan yang tinggi dapat meningkatkankan kepuasan konsumen yang tinggi. Hasil penelitian ini sejalan dengan penelitian Rizan dan Andika (2011) ; Ramli dan 


\section{JURNAL ORGANISASI DAN MANAJEMEN}

Volume 3 (September, 2015)

Sjahruddin (2015). yang menunjukkan bahwa kualitas pelayanan berpengaruh positif dan signifikan terhadap kepuasan. Hal ini menunjukkan bahwa kualitas pelayanan yang tinggi dapat meningkatkan kepuasan konsumen.

\section{c. Pengaruh kepuasan konsumen terhadap minat beli ulang}

Hasil penelitian ini menyatakan bahwa kepuasan konsumen berpengaruh signifikan secara parsial terhadap minat beli ulang. Hal ini terbukti bahwa t-hitung lebih besar dari t-tabel $(3.659>3.423)$ dan tingkat signifikan lebih kecil dari 0.05 $(0.000<0.05)$. Hal ini membuktikan bahwa dengan adanya kepuasan konsumen yang tinggi dapat meningkatkankan minat beli ulang konsumen yang tinggi. Hasil penelitian ini sejalan dengan penelitian Diana Puspitasari (2006) bahwa kepuasan konsumen berpengaruh positif dan signifikan terhadap minat beli konsumen. Hal ini menunjukkan bahwa kepuasan konsumen yang tinggi dapat meningkatkan minat beli.

\section{d. Pengaruh kualitas produk terhadap minat beli ulang}

Hasil penelitian ini menyatakan bahwa kualitas produk tidak berpengaruh signifikan secara parsial terhadap minat beli ulang. Hal ini terbukti bahwa t-hitung lebih kecil dari t-tabel $(0.100>1.293)$ dan tingkat signifikan lebih besar dari 0.05 $(0.921<0.05)$. Hal ini membuktikan bahwa dengan adanya kualitas produk yang rendah dapat menurunkan minat beli ulang konsumen. Hasil penelitian juga tidak sejalan dengan penelitian Basrah Saidani dan Samsul Arifin (2012) yang menunjukkan bahwa kualitas produk berpengaruh positif dan signifikan terhadap minat beli ulang. Hal ini menunjukkan bahwa kualitas produk yang rendah dapat menurunkan minat beli ulang konsumen

\section{e. Pengaruh kualitas pelayanan terhadap minat beli ulang}

Hasil penelitian ini menyatakan bahwa kualitas pelayanan berpengaruh signifikan secara parsial terhadap minat beli ulang. Hal ini terbukti bahwa t-hitung lebih kecil dari t-tabel $(2.090<2.642)$ dan tingkat signifikan lebih kecil dari 0.05 $(0.040<0.05)$. Hal ini membuktikan bahwa dengan adanya kualitas pelayanan yang tinggi dapat meningkatkankan minat beli ulang konsumen yang tinggi. Hasil penelitian ini sejalan dengan penelitian Basrah Saidani dan Samsul Arifin (2012) bahwa kualitas layanan berpengaruh positif dan signifikan terhadap minat beli konsumen. Hal ini menunjukkan bahwa kualitas pelayanan yang tinggi dapat meningkatkan minat beli ulang konsumen.

\section{f. Pengaruh kualitas produk terhadap minat beli ulang melalui kepuasan konsumen}

Hasil penelitian ini menyatakan bahwa kualitas produk tidak berpengaruh signifikan secara parsial terhadap minat beli ulang dengan nilai 0.011 tetapi dengan adanya kepuasan konsumen sebagai variable intervening maka hasil yang didapatkan adalah positif dengan nilai 0.105. Hal ini membuktikan bahwa peranan kepuasan konsumen memperkuat minat beli ulang pada McDonald's Alauddin dan penelitian ini layak untuk diuji. Hasil penelitian ini sejalan dengan penelitian Basrah Saidani dan Samsul Arifin (2012) bahwa secara tidak langsung kepuasan konsumen dapat memperkuat minat beli ulang. Hal ini menunjukkan bahwa kualitas produk 
Volume 3 (September, 2015)

dan kepuasan konsumen yang tinggi dapat meningkatkan minat beli ulang konsumen.

\section{g. Pengaruh kualitas pelayanan terhadap minat beli ulang melalui kepuasan konsumen}

Hasil penelitian ini menyatakan bahwa kualitas pelayanan berpengaruh signifikan secara parsial terhadap minat beli ulang dengan nilai 0.273 dan kepuasan konsumen mampu memediasi antara kualitas pelayanan terhadap minat beli ulang dengan nilai sebesar 0.289. Hal ini membuktikan bahwa peranan kepuasan konsumen dapat memperkuat minat beli ulang pada McDonald's Alauddin dan penelitian ini layak untuk diuji. Hasil penelitian ini sejalan dengan penelitian Basrah Saidani dan Samsul Arifin (2012) bahwa secara tidak langsung kepuasan konsumen dapat memperkuat minat beli ulang. Hal ini menunjukkan bahwa kualitas layanan dan kepuasan konsumen yang tinggi dapat meningkatkan minat beli ulang konsumen.

\section{Kesimpulan}

Kualitas produk memberikan pengaruh yang nyata terhadap kepuasan konsumen. Hal ini disebabkan pada indikator variabel kualitas produk terdapat pengaruh besar yaitu pada indikator rasa yang enak. Dengan adanya informasi yang didapatkan konsumen terhadap menu makanan dan minuman yang disajikan secara lengkap. Hal ini berarti bahwa untuk mengingkatkan kepuasan konsumen, McDonald's harus memberikan informasi tentang kualitas produk yang disajikan kepada konsumennya. Kualitas pelayanan memberikan pengaruh yang nyata terhadap kepuasan konsumen. Hal ini disebabkan pada indikator variabel kualitas pelayanan terdapat pengaruh besar yaitu pada indikator tangibles. Dengan melihat penampilan karyawan McDonald's yang rapih, bersih dan berpakaian yang serasi membuat konsumen merasa senang dan nyaman. Hal ini berarti bahwa untuk mengingkatkan kepuasan konsumen, karyawan McDonald's harus menjaga kebersihan agar membuat konsumen.

Kepuasan konsumen memberikan pengaruh yang nyata terhadap minat beli ulang. Hal ini disebabkan pada indikator variabel kepuasan terdapat pengaruh besar yaitu pada indikator atribut produk. Setelah konsumen melakukan pembelian lagi, maka konsumen akan melakukan pembelian ulang dengan membeli produk yang berbeda. Hal ini berarti bahwa untuk mengingkatkan minat beli ulang konsumen maka McDonald's harus mampu memberikan produk yang baik sehingga membuat konsumen puas.Kualitas produk memberikan pengaruh yang tidak nyata terhadap minat beli ulang. Hal ini disebabkan pada indikator variabel kualitas produk terdapat pengaruh kecil yaitu pada indikator daya tahan kemasan. Dengan memiliki daya tahan yang tinggi pada produk yang dimiliki McDonald's maka konsumen semakin tertarik untuk melakukan pembelian. Hal ini berarti bahwa untuk mengingkatkan minat beli ulang konsumen, maka McDonald's harus meningkatkan daya tahan pada setiap produk yang ditawarkan McDonald's.

Kualitas pelayanan memberikan pengaruh yang nyata terhadap minat beli ulang. Hal ini disebabkan pada indikator variabel kualitas pelayanan terdapat pengaruh besar yaitu pada indikator tangibles. Dengan melihat penampilan karyawan McDonald's yang rapih, bersih dan berpakaian yang serasi membuat konsumen merasa senang dan nyaman. Hal ini berarti bahwa untuk mengingkatkan 


\section{JURNAL ORGANISASI DAN MANAJEMEN}

Volume 3 (September, 2015)

minat beli ulang, karyawan McDonald's harus menjaga kebersihan agar membuat konsumen. Kualitas produk memberikan pengaruh yang tidak nyata terhadap minat beli ulang tetapi dengan adanya kepuasan konsumen sebagai variable intervening maka hasil yang didapatkan adalah positif. Dengan demikian, kepuasan konsumen menjadi hal yang penting dikarenakan variable kepuasan akan menyempurkan pengaruh kualitas produk terhadap minat beli ulang. Hal ini berarti bahwa untuk mengingkatkan minat beli ulang konsumen, maka McDonald's harus meningkatkan kepuasan konsumen. Kualitas pelayanan memberikan pengaruh yang nyata terhadap minat beli ulang tetapi dengan adanya kepuasan konsumen yang memediasi maka akan lebih menguatkan pengaruh kualitas pelayanan terhadap minat beli ulang. Hal ini berarti bahwa untuk mengingkatkan minat beli ulang, maka McDonald's harus mengutamakan kepuasan yang dirasakan oleh konsumen.

Penelitian lanjutan diharapkan dapat dilakukan pada objek dan subjek yang berbeda dengan menambah variabel lain yang berpengaruh terhadap minat beli ulang. Untuk penelitian selanjutnya, disarankan agar lebih memperhatikan waktu penelitian agar tingkat pengembalian (respon rate) kuesioner dapat lebih tinggi dan mendapat hasil yang lebih akurat. Diperlukan upaya yang serius dari pihak manajemen untuk meningkatkan daya tahan kemasan. Peningkatan dapat ditempuh dengan cara meningkatkan daya tahan produk agar dapat dikonsumsi dalam jangka waktu yang panjang. Diperlukan upaya yang serius dari pihak manajemen untuk meningkatkan dukungan (emphaty) bahwa karyawan tidak membuat konsumen merasa spesial. Sebaiknya karyawan mampu mengambil hati seorang konsumen agar konsumen merasa senang selama berada didalam lingkungan McDonald's. Diperlukan upaya yang serius dari pihak manajemen untuk meningkatkan atribut layanan dengan pernyataan McDonald's merupakan salah satu layanan yang terbaik yang pernah konsumen dapatkan. Sebaiknya McDonald's mampu meningkatkan pelayanan kepada konsumennya agar konsumen merasa mendapatkan layanan yang terbaik. Diperlukan upaya yang serius dari pihak manajemen untuk meningkatkan minat transaksional dengan pernyataan konsumen selalu mengkonsumsi produk makanan dan minuman yang disediakan oleh McDonald's.

\section{DAFTAR PUSTAKA}

Aryani, D dan Rosinta, F. (2010). Pengaruh kualitas Layanan Terhadap Kepuasan. Pelanggan Dalam Membentuk Loyalitas Pelanggan. Jurnal Ilmu. Administrasi

Bouman, M., \& Van der Wiele, T. (1992). Measuring service quality in the car service industry: building and testing an instrument, International Journal of Service Industry Management, 3(4), 4-16. http://dx.doi.org/10.1108/09564239210019441.

C. Mowen, John. Michael Minor. (2002). Perilaku Konsumen. Jakarta. Erlangga

Cahyono, M. (2008). Pengaruh kualitas layanan terhadap kepuasan pelanggan brown salon di Tunjungan Plaza Surabaya (Doctoral dissertation, Petra Christian University).

Ferdinand, A. (2002). Kualitas Strategi Pemasaran: Sebuahstudi Pendahuluan. Jurnal Sains Pemasaran Indonesia, 1(1), 107-119.

Haryanto, R. A. (2013). Strategi promosi, kualitas produk, kualitas layanan terhadap kepuasan pelanggan pada restoran McDonald's manado. Jurnal Riset Ekonomi, Manajemen, Bisnis Dan Akuntansi, 1(4).

Author : Arfiani Bahar \& Herman Sjaharuddin (14-34)

Halaman 30

Volume 3 (September, 2015) https://dx.doi.org/10.17605/OSF.IO/TC2FE 
Volume 3 (September, 2015)

Kotler dan Amstrong.(2001).,Prinsip-prinsip pemasaran, jilid 1, Edisi Kedelapan, , Penerbit Erlangga, Jakarta.

Kotler, Philip. (2000). Marketing Management: Edisi Milenium, International Edition. Prentice Hall. International, Inc, New Jersey

Kotler, Philip. (2002). Manajemen Pemasaran Jilid 1 (11th ed.). PT. Indeks. Jakarta Kotler, Philip. (2005). Manajemen Pemasaran Jilid 1 (11th ed.). PT. Indeks. Jakarta

Lembang, R. D., \& Sugiono, S. (2010). Analisis Pengaruh Kualitas Produk, Harga, Promosi, Dan Cuaca Terhadap Keputusan Pembelian Teh Siap Minum Dalam Kemasan Merek Teh Botol Sosro (Studi Kasus Pada Mahasiswa Fakultas Ekonomi S1 Reguler II Universitas Diponegoro) (Doctoral dissertation, Perpustakaan Fakultas Ekonomi UNDIP).

Mandasari, K., \& Soesanto, H. (2011). Analisis Faktor-Faktor yang mempengaruhi minat beli konsumen dalam memilih jasa perhotelan (Studi kasus pada Hotel Grasia Semarang) (Doctoral dissertation, Universitas Diponegoro).

Peterson, C., Maier, S. F., \& Seligman, M. E. (1993). Learned helplessness: A theory for the age of personal control. Theory for the Age of Personal.

Puspitasari, D. (2006). Analisis pengaruh persepsi kualitas dan kepuasan pelanggan terhadap minat beli ulang (Studi kasus pada maskapai penerbangan garuda keberangkatan Semarang) (Doctoral dissertation, program Pascasarjana Universitas Diponegoro).

Rahma, E. S. (2007). Analisis pengaruh kualitas layanan dan citra merek terhadap minat beli dan dampaknya pada keputusan pembelian (studi pada pengguna telepon seluler merek sony ericson di kota Semarang) (Doctoral dissertation, Program Pasca Sarjana Universitas Diponegoro).

Ramli, A. H., \& Sjahruddin, H. (2015). Building patient loyalty in healthcare services. International Review of Management and Business Research, 4(2), 391.

Rizan, M., \& Andika, F. (2011). Pengaruh Kualitas Produk Dan Kualitas Pelayanan terhadap Kepuasan Pelanggan (Survei Pelanggan Suzuki, Dealer Fatmawati, Jakarta Selatan). JRMSI-Jurnal Riset Manajemen Sains Indonesia, 2(2), 130150.

Saidani, B., \& Arifin, S. (2012). Pengaruh kualitas produk dan kualitas layanan terhadap kepuasan konsumen dan minat beli pada ranch market. JRMSI-Jurnal Riset Manajemen Sains Indonesia, 3(1), 1-22.

Schneider, B., \& White, S. S. (2004). Service quality: Research perspectives (Vol. 107). Sage.

Sugiyono. (2013). Metode Penelitian Pendidikan Pendekatan Kuantitatif,. Kualitatif, dan R\&D. Bandung

Sundalangi, Marchelyno., Mandey, Silvya L. dan Jorie, Rotinsulu Jopie. (2014) Kualitas Produk, Daya Tarik Iklan, Dan Potongan Harga Terhadap Minat Beli Konsumen Pada Pizza Hut Manado, Fakultas Ekonomi dan Bisnis Jurusan Manajemen, Universitas Sam Ratulangi, Manado.

Thamrin, S. D. (2003). Studi Mengenai Proses Adopsi Konsumen Pasca Masa Tayang Iklan Produk" Xon-Ce" di SURABAYA. Jurnal Sains Pemasaran Indonesia, 2(2), 141-154.

Zeithaml V.A., Parasuraman A. ,Berry L.L.(1990). Delivering quality service: balancing customer perceptions and expectation. United States of America: The Free Press.

Author : Arfiani Bahar \& Herman Sjaharuddin (14-34)

Halaman 31

Volume 3 (September, 2015) https://dx.doi.org/10.17605/OSF.IO/TC2FE 
Volume 3 (September, 2015)

\section{Lampiran Kuesioner}

\section{PETUNJUK PENGISIAN INSTRUMEN PENELITIAN (ANGKET)}

1. Untuk mengisi identintas, bapak/ibu/saudara (i) cukup mengisi titik atau coret yang tidak perlu

2. Mohon bapak/ibu memberikan jawaban yang sebenarnya sesuai dengan kondisi yang atau fakta yang diraskan.

3. Jawaban yang bapak/ibu berikan kami jamin kerahasiaannya dan hanya dipergunakan sebatas untuk kepentingan penelitian serta tidak memberikan pengaruh negatif baik secara pribadi maupun pada perusahaan.

4. Berilah tanda $(\mathrm{X})$ pada kolom sesuai dengan jawaban Bapak/Ibu/Saudara, dan kemukakan alasan terhadap setiap alternatip pilihan/jawaban yang disediakan dalam pertanyaan kuesioner adalah :

$\begin{array}{lrr}\text { Sangat Baik/Sangat Setuju } & \text { Point } & 5 \\ \text { Baik/Setuju } & \text { Point } & 4 \\ \text { Netral } & \text { Point } & 3 \\ \text { Tidak Baik /Tidak Setuju } & \text { Point } & 2 \\ \text { Sangat Tidak Baik /Sangat Tidak Setuju } & \text { Point } & 1\end{array}$

\section{Identintas Responden:}

1. Nama

2. Jenis kelamin

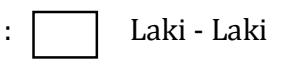

$\square$ Perempuan

3. Umur

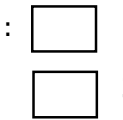

15 - 24 Tahun

25 - 34 Tahun

35 - 44 Tahun

4. Lama mengkonsumsi
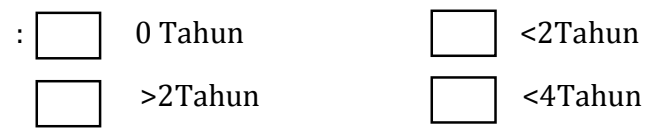

5. Pekerjaan

Mahasiswa / Pelajar

Karyawan

Ibu Rumah Tangga

“Pernyataan Kualitas Produk (X)

\begin{tabular}{|c|c|c|c|c|c|c|}
\hline \multirow[b]{2}{*}{ No. } & \multirow[b]{2}{*}{ Pernyataan } & \multicolumn{5}{|c|}{ Alternative Jawaban } \\
\hline & & $\begin{array}{c}1 \\
\text { (STS) }\end{array}$ & $\begin{array}{c}2 \\
(\mathrm{TS})\end{array}$ & $\begin{array}{c}3 \\
(N)\end{array}$ & $\begin{array}{c}4 \\
(S)\end{array}$ & $\begin{array}{c}5 \\
(S S)\end{array}$ \\
\hline \multirow[t]{3}{*}{1.} & \multicolumn{6}{|l|}{ Rasa Yang Enak $\left(X_{11}\right)$} \\
\hline & $\begin{array}{l}\text { a. McDonald's memiliki rasa khas pada setiap } \\
\text { produk makanan dan minumannya }\end{array}$ & & & & & \\
\hline & $\begin{array}{l}\text { b. Cita rasa pada produk makanan dan minuman } \\
\text { yang ditawarkan oleh McDonald's sesuai } \\
\text { dengan harapan saya }\end{array}$ & & & & & \\
\hline 2. & \multicolumn{6}{|l|}{ Fitur Produk $\left(X_{12}\right)$} \\
\hline
\end{tabular}




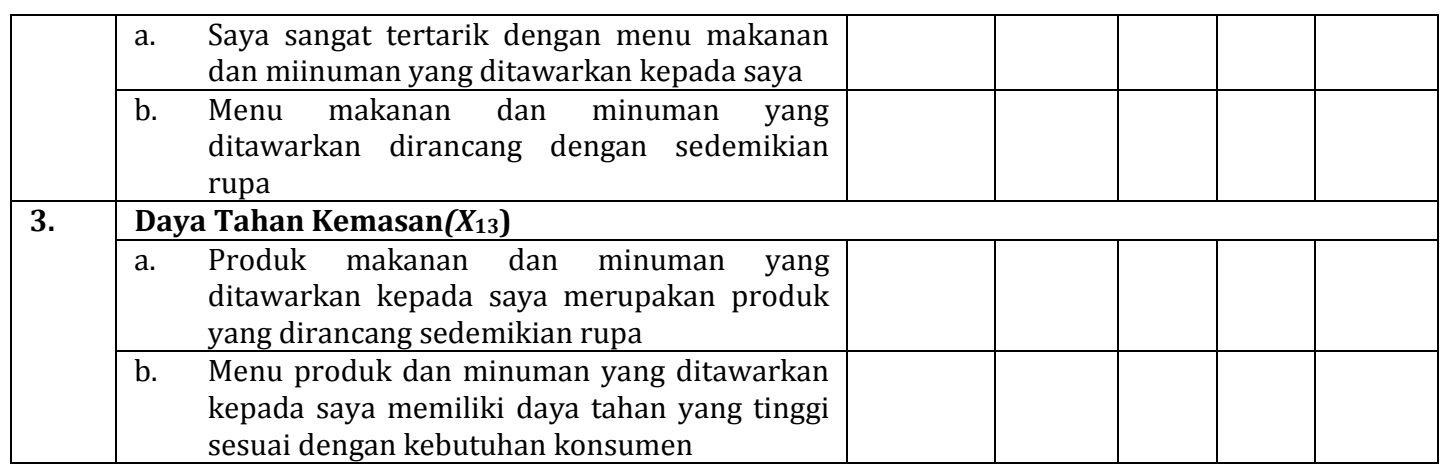

Pernyataan Kualitas Pelayanan $\left(\mathrm{X}_{2}\right)$

\begin{tabular}{|c|c|c|c|c|c|c|}
\hline \multirow[b]{2}{*}{ No. } & \multirow[b]{2}{*}{ Pernyataan } & \multicolumn{5}{|c|}{ Alternative Jawaban } \\
\hline & & $\begin{array}{c}1 \\
\text { (STS) }\end{array}$ & $\begin{array}{c}2 \\
(\mathrm{TS})\end{array}$ & $\begin{array}{c}3 \\
(\mathrm{~N})\end{array}$ & $\begin{array}{c}4 \\
(S)\end{array}$ & $\begin{array}{c}5 \\
(\mathrm{SS})\end{array}$ \\
\hline \multirow[t]{3}{*}{1.} & \multicolumn{6}{|l|}{ Bukti Fisik (Tangibles) $\left(X_{21}\right)$} \\
\hline & $\begin{array}{l}\text { a. Saya merasa nyaman dengan penampilan } \\
\text { ruangan dan fasilitas yang ada pada } \\
\text { MCDONALD'S }\end{array}$ & & & & & \\
\hline & $\begin{array}{l}\text { b. Karyawan MCDONALD'S bersih, rapih, dan } \\
\text { berpakaian yang serasi }\end{array}$ & & & & & \\
\hline \multirow[t]{3}{*}{2.} & \multicolumn{6}{|l|}{ Keandalan (Realibility) $\left(X_{22}\right)$} \\
\hline & $\begin{array}{l}\text { a. Saya sangat terpuaskan dengan menu produk } \\
\text { makanan dan minuman yang ditawarkan } \\
\text { kepada saya }\end{array}$ & & & & & \\
\hline & $\begin{array}{llll}\text { b. } & \begin{array}{l}\text { Kepuasan yang saya peroleh } \\
\text { mengkonsumsi produk } \\
\text { periode waktu yang lama }\end{array} & \text { bertahan } & \text { dalam } \\
\end{array}$ & & & & & \\
\hline \multirow[t]{3}{*}{3.} & \multicolumn{6}{|l|}{ Daya Tangkap (Responsiveness) $\left(X_{23}\right)$} \\
\hline & $\begin{array}{ll}\text { a. MCDONALD'S memberikan layanan yang } \\
\text { ekstra untuk memenuhi keinginan pelanggan }\end{array}$ & & & & & \\
\hline & $\begin{array}{ll}\text { b. Karyawan MCDONALD'S memberikan layanan } \\
\text { yang cepat }\end{array}$ & & & & & \\
\hline \multirow[t]{3}{*}{4.} & \multicolumn{6}{|l|}{ Jaminan (Assurance) $\left(X_{24}\right)$} \\
\hline & $\begin{array}{ll}\text { a. Karyawan MCDONALD'S mebuat saya merasa } \\
\text { aman }\end{array}$ & & & & & \\
\hline & $\begin{array}{lll}\text { b. } & \begin{array}{l}\text { Karyawan MCDONALD'S dapat menjawab } \\
\text { pertanyaan saya dengan baik }\end{array} \\
\end{array}$ & & & & & \\
\hline \multirow[t]{3}{*}{5.} & \multicolumn{6}{|l|}{ Dukungan (Empathy) (X25) } \\
\hline & $\begin{array}{lll}\text { a. } & \begin{array}{l}\text { MCDONALD'S sangat memperhatikan } \\
\text { kepentingan saya }\end{array} & \\
\end{array}$ & & & & & \\
\hline & $\begin{array}{lll}\text { b. Karyawan MCDONALD'S membuat saya } \\
\text { merasa special. }\end{array}$ & & & & & \\
\hline
\end{tabular}

\section{Pernyataan Kepuasan Konsumen ( $\left.\mathrm{Y}_{1}\right)$}

\begin{tabular}{|c|c|c|c|c|c|c|}
\hline \multirow[b]{2}{*}{ No. } & \multirow[b]{2}{*}{ Pernyataan } & \multicolumn{5}{|c|}{ Alternative Jawaban } \\
\hline & & $\begin{array}{c}1 \\
\text { (STS) }\end{array}$ & $\begin{array}{c}2 \\
(\mathrm{TS})\end{array}$ & $\begin{array}{c}3 \\
(\mathrm{~N})\end{array}$ & $\begin{array}{c}4 \\
(S)\end{array}$ & $\begin{array}{c}5 \\
(\mathrm{SS})\end{array}$ \\
\hline \multirow[t]{3}{*}{1.} & \multicolumn{6}{|c|}{ Atribut Layanan (Attributes Related To Service) (Y11) } \\
\hline & $\begin{array}{l}\text { a. Saya merasa layanan yang diberikan oleh } \\
\text { McDonald's kepada saya sesuai dengan yang } \\
\text { saya harapkan }\end{array}$ & & & & & \\
\hline & $\begin{array}{l}\text { b. McDonald's merupakan salah satu layanan } \\
\text { yang terbaik yang pernah saya dapatkan }\end{array}$ & & & & & \\
\hline 2. & \multicolumn{6}{|l|}{ Atribut Produk (Attributes Related To Product) (Y12) } \\
\hline
\end{tabular}


Volume 3 (September, 2015)

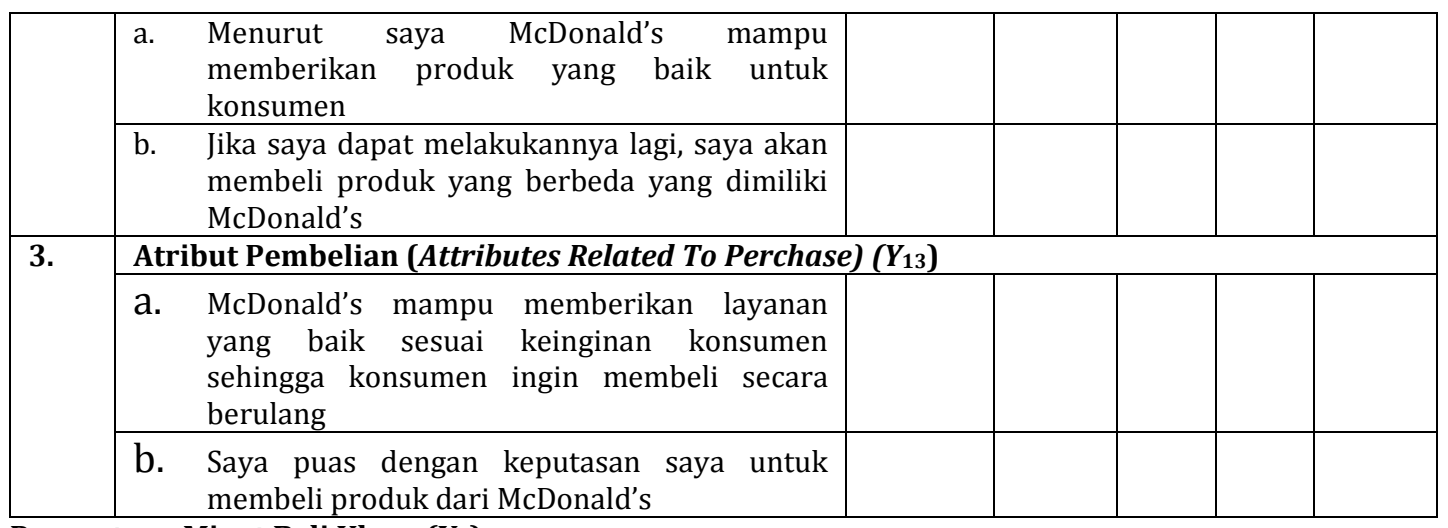

\section{Pernyataan Minat Beli Ulang ( $\left.\mathrm{Y}_{2}\right)$}

\begin{tabular}{|c|c|c|c|c|c|c|}
\hline \multirow[b]{2}{*}{ No. } & \multirow[b]{2}{*}{ Pernyataan } & \multicolumn{5}{|c|}{ Alternative Jawaban } \\
\hline & & $\begin{array}{c}1 \\
\text { (STS) }\end{array}$ & $\begin{array}{c}2 \\
(\mathrm{TS})\end{array}$ & $\begin{array}{c}3 \\
(\mathrm{~N})\end{array}$ & $\begin{array}{c}4 \\
(S)\end{array}$ & $\begin{array}{c}5 \\
(S S) \\
\end{array}$ \\
\hline \multirow[t]{3}{*}{1.} & \multicolumn{6}{|l|}{ Minat Transaksional $\left(Y_{21}\right)$} \\
\hline & $\begin{array}{l}\text { a. Saya selalu mengkonsumsi produk makanan } \\
\text { dan minuman yang disediakan oleh } \\
\text { McDonald's }\end{array}$ & & & & & \\
\hline & $\begin{array}{l}\text { b. McDonald's membuat saya ketagihan dengan } \\
\text { menu makananan dan minuman yang ada }\end{array}$ & & & & & \\
\hline \multirow[t]{3}{*}{2.} & \multicolumn{6}{|l|}{ Minat Referensial $\left(Y_{22}\right)$} \\
\hline & $\begin{array}{l}\text { a. Saya senantiasa merekomendasikan menu } \\
\text { makanan dan minuman yang baru kepada } \\
\text { kerabat }\end{array}$ & & & & & \\
\hline & $\begin{array}{l}\text { b. McDonald's selalu mempunyai produk } \\
\text { makanan dan minuman yang berkualitas } \\
\text { sehingga saya selalu memberikan informasi ke } \\
\text { orang lain }\end{array}$ & & & & & \\
\hline \multirow[t]{3}{*}{3.} & \multicolumn{6}{|l|}{ Minat Preferensial $\left(Y_{23}\right)$} \\
\hline & McDonald's selalu menjadi pilihan utama saya & & & & & \\
\hline & $\begin{array}{l}\text { b. Saya akan beralih ke Produk lain apabila } \\
\text { produk makanan dan minuman yang ada di } \\
\text { McDonald's tidak sesuai dengan harapan }\end{array}$ & & & & & \\
\hline \multirow[t]{3}{*}{4.} & \multicolumn{6}{|l|}{ Minat Eksploratif $\left(Y_{24}\right)$} \\
\hline & $\begin{array}{l}\text { a. Saya akan selalu merekomendasikan produk } \\
\text { makanan dan minuman yang saya favoritkan } \\
\text { agar tetap dipertahankan dalam daftar menu } \\
\text { di McDonald's }\end{array}$ & & & & & \\
\hline & $\begin{array}{l}\text { b. Saya akan mencari informasi tentang menu } \\
\text { makanan dan minuman yang terbaru di } \\
\text { McDonald's }\end{array}$ & & & & & \\
\hline
\end{tabular}

Author : Arfiani Bahar \& Herman Sjaharuddin (14-34) 